IDS WORKING PAPER 320

\title{
Climate Change Adaptation, Disaster Risk Reduction and Social Protection: Complementary Roles in Agriculture and Rural Growth?
}

\author{
Mark Davies, Bruce Guenther, Jennifer Leavy, Tom Mitchell \\ and Thomas Tanner \\ Centre for Social Protection and Climate Change and Development Centre
}

February 2009 
Climate Change Adaptation, Disaster Risk Reduction and Social Protection: Complementary Roles in Agriculture and Rural Growth?

Mark Davies, Bruce Guenther, Jennifer Leavy, Tom Mitchell and Thomas Tanner

IDS Working Paper 320

First published by the Institute of Development Studies in February 2009

(C) Institute of Development Studies 2009

ISSN: 2040-0209 ISBN: 9781858645786

A catalogue record for this publication is available from the British Library.

All rights reserved. Reproduction, copy, transmission, or translation of any part of this publication may be made only under the following conditions:

- with the prior permission of the publisher; or

- with a licence from the Copyright Licensing Agency Ltd., 90 Tottenham Court Road, London W1P 9HE, UK, or from another national licensing agency; or

- under the terms set out below.

This publication is copyright, but may be reproduced by any method without fee for teaching or non-profit purposes, but not for resale. Formal permission is required for all such uses, but normally will be granted immediately. For copying in any other circumstances, or for re-use in other publications, or for translation or adaptation, prior written permission must be obtained from the publisher and a fee may be payable.

Available from:

Communication Unit

Institute of Development Studies

at the University of Sussex

Brighton BN1 9RE, UK

Tel: +44(0) 1273915637

Fax: +44 (0) 1273621202

E-mail: bookshop@ids.ac.uk

Web: www.ids.ac.uk/ids/bookshop

Typeset by IDS, Brighton UK. Printed by RPM Print \& Design, Chichester UK

IDS is a charitable company limited by guarantee and registered in England (No. 877338) 


\title{
Climate Change Adaptation, Disaster Risk Reduction and Social Protection: Complementary Roles in Agriculture and Rural Growth?
}

\author{
Mark Davies, Bruce Guenther, Jennifer Leavy, Tom Mitchell \\ and Thomas Tanner
}

\section{Summary}

Reliance on subsistence agriculture means the impact of stresses and shocks (such as droughts or floods) are felt keenly by rural poor people, who depend directly on food system outcomes for their survival, with profound implications for the security of their livelihoods and welfare. However, such stresses and shocks will not necessarily lead to negative impacts, as risks and uncertainties, often associated with seasonality, are embedded in the practice of agriculture and there is considerable experience of coping and risk management strategies among people working in this sector. With climate change, the magnitude and frequency of stresses and shocks is changing and approaches such as social protection, disaster risk reduction (DRR) and climate change adaptation (CCA) will be needed to bolster local resilience and supplement people's experience.

This study examines the opportunities for linking social protection, CCA and DRR in the context of agriculture and rural growth, exploring whether linking these three approaches together will help enhance resilience to shocks and stresses in agriculture-dependent rural communities. The study does this by (i) reviewing conceptual and policy-related similarities and differences between the three disciplines, by (ii) collecting evidence from case studies where climate changeresilient social protection approaches have been trialled and by (iii) developing an adaptive social protection framework that highlight opportunities better coordination.

This paper suggests social protection and DRR measures designed to limit damages from shocks and stresses may not be sufficient in the longer term. For social protection to be resilient to climate change impacts, it will need to consider how reducing dependence on climate sensitive livelihood activities can be part of adaptive strategies. Similarly, CCA and DRR cannot effectively address the root causes of poverty and vulnerability without taking a differentiated view of poverty, something that further integration with social protection can help with. 
Keywords: social protection; climate change adaptation; disaster risk reduction; adaptive social protection; agriculture; rural growth; risk; resilience.

Mark Davies is a manager of the Centre for Social Protection at the Institute of Development Studies, having previously worked with the UK Department for International Development in Africa and London as a livelihoods advisor. He has practical and research experience working in social protection, food security, livelihoods, poverty and vulnerability. He has worked extensively in Ghana, Kenya and Malawi, working within bilateral agencies, multilateral organisations, in close partnership with government and NGOs. Mark has in-depth knowledge of the policies, institutions and processes that influence both social protection policy and programming.

Bruce Guenther is a recent MPhil graduate of the Institute of Development Studies and is currently a disaster response coordinator for Mennonite Central Committee in Winnipeg, Canada. His most recent research has explored various dimensions of social protection including its role in promoting climate change adaptation and reducing disaster risk, linkages with agricultural growth and the politics of social protection. The primary focus of this work has been Ethiopia's Productive Safety Net Programme.

Jennifer Leavy is an Agricultural Economist based in the Vulnerability and Poverty Reduction Team at IDS, with research and consultancy experience in sub-Saharan Africa, South and South-East Asia. Interests include rural institutions, poverty and livelihoods; work and labour exchange; agricultural commercialisation; social network analysis; combing quantitative, qualitative and participatory methods in research and analysis.

Tom Mitchell is a Research Fellow in the Climate Change and Development Centre at IDS. With a PhD in Geography, much of Tom's work focuses on the development and poverty dimension of climate change and disasters through his ongoing projects in the Philippines, El Salvador, Indonesia and parts of Africa. Tom coordinates the programmes on 'Children in a Changing Climate' and 'Pro-poor Climate and Disaster Governance' and manages a UK-based network of organisations examining the links between climate change adaptation and chronic poverty.

Thomas Tanner is a Research Fellow at IDS specialising in climate change adaptation and its relation to development theory, policy and practice. His work focuses on international climate policy, linking poverty and climate change: child-centred approaches to disaster risk reduction and adaptation; organisational responses to climate change; and networks and knowledge services for adaptation. He has previously worked for the UK Department for International Development and the United Nations Development Programme on climate change adaptation policy and programmes, and has been a negotiator for the UN conventions on climate change and desertification. 


\section{Contents}

Summary 3

Keywords and author notes $\quad 4$

Acknowledgements 6

$\begin{array}{lr}\text { Executive summary } & 7\end{array}$

1 Introduction and rationale 10

2 Policy context for linkages in agriculture 11

2.1 Agriculture and rural growth 11

2.2 Social protection 12

2.3 Disaster risk reduction (DRR) 13

2.4 Climate change adaptation 13

3 Conceptual linkages: parallels and differences 14

3.1 Why the limited links to date? 14

3.2 Towards transformative and adaptive approaches through social protection

3.3 Timeframe and limits: driving longer term perspectives on social protection

3.4 People-centred and social aspects 17

3.5 Institutional capacity and coordination 18

3.6 Instrumentalism vs rights based approaches 18

4 Linkages in practice: investing the evidence base 19

4.1 Weather-indexed crop insurance $\quad 20$

4.2 Asset restocking 21

4.3 Starter packs and seed fairs $\quad 22$

4.4 Cash transfers 23

4.5 Summary of lessons from case studies $\quad 25$

5 Conclusions and recommendations 26

5.1 Developing 'adaptive social protection' 26

5.2 Recommendations for further areas of work 27

Annex: Dimensions of social protection, DRR and climate change adaptation 


\section{Figure and tables}

Figure 5.1 Adaptive social protection

Table ES1 Key characteristics of social protection, adaptation and DRR

Table ES2 Lessons from linking social protection, DRR and adaptation in practice

Table 3.1 Key characteristics of social protection, adaptation and DRR

Table 3.2 Promoting adaptation through social protection

Table 4.1 Benefits and challenges of social protection for adaptation and DRR

Table 5.2 Opportunities and further requirements

Table A1 Dimensions of social protection, DRR and climate change adaptation policies and approaches

\section{Acknowledgements}

This working paper is the product of work commissioned by the Department for International Development's Renewal Natural Resources and Agriculture Team within Policy Division. Grateful thanks to Tim Waites and other DFID environment and livelihoods advisers around the world for inputs and feedback. Thanks also to Rachel Sabates-Wheeler and Stephen Devereux at IDS for their valuable review comments. 


\section{Executive summary}

Global processes and crises are changing and deepening the risks already faced by poor and vulnerable people in rural areas, particularly those involved in agriculture and other ecosystem-dependent livelihoods. Reliance on subsistence agriculture means the impact of stresses and shocks (such as droughts or floods) are felt keenly by rural poor people, who depend directly on food system outcomes for their survival. This has profound implications for the security of their livelihoods and for their welfare. However, such stresses and shocks will not necessarily lead to negative impacts, as risks and uncertainties, often associated with seasonality, are embedded in the practice of agriculture and there is considerable experience of coping and risk management strategies among people working in this sector. With climate change, the magnitude and frequency of stresses and shocks is changing and approaches such as social protection, disaster risk reduction (DRR) and climate change adaptation will be needed to bolster local resilience and supplement people's experience.

This study examines the opportunities for linking social protection, adaptation and $\mathrm{DRR}$ in the context of agriculture and rural growth, exploring whether linking these three approaches together will help enhance resilience to shocks and stresses in agriculture-dependent rural communities. The study does this by (i) reviewing conceptual and policy-related similarities and differences between the three disciplines, by (ii) collecting evidence from case studies where climate changeresilient social protection approaches have been trialled and by (iii) developing an adaptive social protection framework that highlights opportunities for better coordination.

\section{Social protection, adaptation and DRR: similarities and differences}

Social protection, adaptation and DRR have much in common, but have developed as separate disciplines over the last two decades (see Table ES1 below). They all seek to mitigate risks faced by poor people; they tackle the impact of, and seek to build resilience against, shocks and stresses on livelihoods and they are all in relatively formative stages of development and testing, rather than established components of development and poverty reduction. However, to date, despite ongoing efforts to link disasters and climate change communities (Sperling and Szekely 2005; DFID 2007), there has been little cross-fertilisation with social protection policies and practices.

Adapting to the impacts of climate change has grown from a minor environmental concern to a major challenge for human development and is a crucial element in eradicating poverty and achieving the MDGs (UNDP 2007; Tanner and Mitchell 2008a). Similarly, the disasters community has responded to the growing impacts of natural hazards by refocusing its attention away from humanitarian relief and rehabilitation toward preventing and reducing disaster risk. Social protection has also rapidly moved up the development policy agenda and growing experience, together with improved evidence, suggests that it can effectively contribute to poverty reduction and move people into productive livelihoods. While social 
protection aims to build resilience to some climate-related disasters, insufficient attention has been played in the social protection sphere to the long-term risks posed by climate change. However, social protection approaches could inform DRR and climate change adaptation based on established implementation frameworks for vulnerability reduction.

\section{Table ES1 Key characteristics of social protection, adaptation and DRR}

\begin{tabular}{|l|l|l|l|}
\hline & \multicolumn{1}{|c|}{ Social protection } & \multicolumn{1}{|c|}{ Adaptation } & \multicolumn{1}{|c|}{ DRR } \\
\hline $\begin{array}{l}\text { Core disciplinary } \\
\text { grounding }\end{array}$ & $\begin{array}{l}\text { Development and } \\
\text { welfare economics }\end{array}$ & $\begin{array}{l}\text { Social development } \\
\text { and physical sciences }\end{array}$ & Physical sciences \\
\hline Dominant focus & $\begin{array}{l}\text { Implementation of } \\
\text { measures to manage } \\
\text { risk }\end{array}$ & $\begin{array}{l}\text { Enabling processes of } \\
\text { adaptation }\end{array}$ & $\begin{array}{l}\text { Prevention of disaster } \\
\text { events }\end{array}$ \\
\hline $\begin{array}{l}\text { Main shocks and } \\
\text { stresses addressed }\end{array}$ & Multiple & Climate-related & $\begin{array}{l}\text { All natural hazard- } \\
\text { related, including } \\
\text { climate }\end{array}$ \\
\hline $\begin{array}{l}\text { International } \\
\text { coordination }\end{array}$ & $\begin{array}{l}\text { Informal, OECD task } \\
\text { group }\end{array}$ & $\begin{array}{l}\text { UNFCCC - Nairobi } \\
\text { Work Programme } \\
\text { and bilateral }\end{array}$ & $\begin{array}{l}\text { UN-ISDR Hyogo } \\
\text { Framework for Action }\end{array}$ \\
\hline Main funding & $\begin{array}{l}\text { Coordinated inter- } \\
\text { national funds: Global } \\
\text { Environment Facility, } \\
\text { UNFCCC/Kyoto } \\
\text { Protocol funds. } \\
\text { Ad hoc bilateral }\end{array}$ & $\begin{array}{l}\text { Coordinated } \\
\text { international funding: } \\
\text { ISDR, GFDRR. } \\
\text { Ad hoc civil } \\
\text { sponsored and } \\
\text { bilateral }\end{array}$ \\
\hline
\end{tabular}

\section{Implications of climate change for social protection: the evidence base}

Within the agricultural sector, social protection measures that could both build resilience to climate change and benefit from integrating climate change adaptation include: weather-indexed crop insurance, asset restocking (including direct livestock provision), and cash transfers. Assessing evidence from country's experiences of these measures indicates ways in which social protection measures could better integrate DRR and climate change adaptation (see Table ES2).

\section{Adaptive social protection}

The evidence presented in this paper suggests social protection and DRR measures designed to limit damages from shocks and stresses may simply not be sufficient in the longer term. For social protection to be resilient to climate change impacts, it will therefore need to consider how reducing dependence on climate sensitive livelihood activities can be part of adaptive strategies. Similarly, adaptation and DRR cannot effectively address the root causes of poverty and vulnerability without taking a differentiated view of poverty, something that further 


\section{Table ES2 Lessons from linking social protection, DRR and adaptation in practice}

\begin{tabular}{|c|c|c|}
\hline $\begin{array}{l}\text { Social } \\
\text { protection } \\
\text { measure }\end{array}$ & Benefits for adaptation and DRR & Challenges \\
\hline $\begin{array}{l}\text { Weather- } \\
\text { based crop } \\
\text { insurance }\end{array}$ & $\begin{array}{l}\text { - Rapid payouts possible } \\
\text { - Guards against the adverse selection } \\
\text { and moral hazard } \\
\text { - Frees up assets for investment in } \\
\text { adaptive capacity } \\
\text { - Easily linked to trends and } \\
\text { projections for climate change } \\
\text { - Supports adaptive flexibility and risk } \\
\text { taking }\end{array}$ & $\begin{array}{l}\text { - Targeting marginal farmers } \\
\text { - Tackling differentiated gender impacts } \\
\text { - Affordable premiums for poor } \\
\text { - Subsidising capital costs } \\
\text { - Integrating climate change proj- } \\
\text { ections into financial risk assessment } \\
\text { - Guarantee mechanisms for re- } \\
\text { insurance }\end{array}$ \\
\hline $\begin{array}{l}\text { Seed } \\
\text { transfer }\end{array}$ & $\begin{array}{l}\text { - Boost agricultural production and } \\
\text { household food security } \\
\text { - Post disaster response tool } \\
\text { - Seed varieties can be tailored to } \\
\text { changing local environmental } \\
\text { conditions } \\
\text { - Cost effectiveness of seed voucher } \\
\text { and fair projects } \\
\text { - Fairs promote crop diversity and } \\
\text { information sharing }\end{array}$ & $\begin{array}{l}\text { - Ensuring locally appropriate seed } \\
\text { and fertiliser varieties } \\
\text { - Protection of crop diversity } \\
\text { - Reduce distortion of local markets } \\
\text { - Focus on access rather than only } \\
\text { availability } \\
\text { - Inclusive approach that draws in } \\
\text { marginal farmers }\end{array}$ \\
\hline $\begin{array}{l}\text { Asset } \\
\text { transfer }\end{array}$ & $\begin{array}{l}\text { - Ability to target most vulnerable } \\
\text { people } \\
\text { - Easily integrated in livelihoods } \\
\text { programmes }\end{array}$ & $\begin{array}{l}\text { - Ensuring local appropriateness of } \\
\text { assets } \\
\text { - Integrating changing nature } \\
\text { environmental stresses in asset } \\
\text { selection }\end{array}$ \\
\hline $\begin{array}{l}\text { Cash } \\
\text { transfers }\end{array}$ & $\begin{array}{l}\text { - Targeting of most vulnerable to } \\
\text { climate shocks } \\
\text { - Smoothing consumption allowing } \\
\text { adaptive risk-taking and investment } \\
\text { - Flexibility enhanced to cope with } \\
\text { climate shocks }\end{array}$ & $\begin{array}{l}\text { - Ensuring adequate size and } \\
\text { predictability of transfers } \\
\text { - Long term focus to reduce risk over } \\
\text { extended timeframes } \\
\text { - Demonstrating economic case for } \\
\text { cash transfers related to climate } \\
\text { shocks } \\
\text { - Use of socio-ecological vulnerability } \\
\text { indices for targeting }\end{array}$ \\
\hline
\end{tabular}

integration with social protection can help with. To offer a way forward, the study concludes by suggesting follow-up work and by establishing the concept of adaptive social protection, which features:

- An emphasis on transforming productive livelihoods as well protecting, and adapting to changing climate conditions rather than simply reinforcing coping mechanisms. 
- Grounding in an understanding of the structural root causes of poverty in a particular region or sector, permitting more effective targeting of vulnerability to multiple shocks and stresses.

- Incorporation of rights-based rationale for action, stressing equity and justice dimensions of chronic poverty and climate change adaptation in addition to instrumentalist rationale based primarily on economic efficiency.

- An enhanced role for research from both the natural and social sciences to inform the development and targeting of social protection policies and measures in the context of the burden of both geophysical hazards and changing climate-related hazards.

- A longer-term perspective for social protection policies that takes into account the changing nature of shocks and stresses.

\section{Introduction and rationale}

Social protection, climate change adaptation and disaster risk reduction (DRR) have developed as three separate fields over the last two decades, all rising prominently in recent years. As the impacts of climate change have become better understood, climate change adaptation has grown from a minor environmental concern to a major challenge for human development and a crucial element in eradicating poverty and achieving the MDGs (UNDP 2007; Tanner and Mitchell 2008a).

Over a similar period, the disasters community has focused beyond humanitarian relief and rehabilitation activities towards preventing and reducing the risk of disasters. Major disaster events such as the Iran (2003) and Pakistan (2005) earthquakes and the South Asian tsunami (2004) have added impetus to this paradigm shift.

Social protection has witnessed a similarly rapid rise up the development policy agenda and experience, together with improved evidence, suggests that it can effectively contribute to poverty reduction and move people into productive livelihoods. Many of the policy instruments associated with social protection have targeted and contributed to reducing vulnerability related to the variations and extremes in climate and their impact on rural livelihoods.

This study explores the potential policy linkages and complementarities of the three fields in the context of agricultural growth. To date, despite ongoing efforts to link disasters and climate change communities, there has been little crossfertilisation with social protection policies and practices. The study introduces the background to the three fields and outlines existing linkages in discourse, policy and practice. It assesses good practice that might effectively contribute to agricultural growth, before recommending practical ways forward and options for further work. 


\section{Policy context for linkages in agriculture}

This section briefly introduces the context of agriculture and rural growth to explore social protection, adaptation and DRR themes and related DFID policies. It then briefly highlights key similarities and differences between the three fields.

\subsection{Agriculture and rural growth}

The majority of the world's poorest people live and work in rural areas. Their livelihoods and survival depend heavily on agriculture and other rural sectors strongly reliant on natural resources. As well as being central to the lives of poor people in developing countries, agriculture sectoral growth has strong links to growth in other sectors of the economy.

Weather-related shocks and stresses are significant to agricultural production, with impacts on both small-scale producers and also those working in larger-scale agriculture and non-agricultural enterprises in rural areas. Shocks can be covariate (affecting everyone at the same time such as drought) and/or idiosyncratic (affecting only a particular household or individual). However, shocks will not necessarily lead to detrimental impacts and there is a considerable literature and experience on coping and risk management strategies (UNFCCC 2007).

Effects of shocks and seasonality can threaten food security. In many rural areas markets for food are non-existent, weak or fragmented and characterised by seasonal price hikes, so most households will produce at the very least for their own food needs. High reliance on subsistence agriculture means the impact of stresses and shocks (such as droughts or floods) are felt directly by rural poor people who depend directly on food system outcomes for their survival and are less able to substitute losses by buying food in the market (FAO 2005).

DFID's Agricultural Policy (DFID 2005b) focuses on increasing agricultural productivity as a crucial step in achieving economic growth and poverty reduction, recognising that agriculture's importance to poverty reduction reaches far beyond its direct impact on farmers' incomes. In the poorest countries in the earliest stages of development, increasing agricultural productivity encourages economic development outside agriculture where growth and job creation are faster and wages higher, and is a critical pathway to more diversified and faster economic growth.

To maximise impact on poverty, the policy paper identifies six guiding principles for policy and public spending decisions. Policies should:

- Reflect the stage of a country's development;

- Give priority to agricultural development in places where significant productivity gains are possible and potential links to the wider economy are strongest; 
- Give priority to strategies designed to overcome the most significant obstacles to increased productivity and employment;

- Focus on demand and market opportunities;

- Make social protection complementary to agricultural growth;

- Ensure the sustainable use of the main productive resources.

\subsection{Social protection}

Social protection describes: all initiatives that transfer income or assets to the poor, protect the vulnerable against livelihood risks, and enhance the social status and rights of the marginalised.

Social protection for the most vulnerable people has become a key policy response to risk and vulnerability in the agriculture sector (Sabates-Wheeler et al. 2007a, Farrington et al. 2004a, 2004b). Agricultural policies can help people improve their livelihoods and security; the right social protection can help rural people not only to expand their assets, but to use them efficiently and adopt higher return activities.

Social protection is a field of enormous scope. For the purposes of this study social protection describes: all initiatives that transfer income or assets to the poor, protect the vulnerable against livelihood risks, and enhance the social status and rights of the marginalised. Its overall objectives are to extend the benefits of economic growth and reduce the economic or social vulnerability of poor, vulnerable and marginalised people (IDS 2006; Devereux and Sabates-Wheeler 2004).

This definition is useful because it allows the distinction between four categories of objectives: provision measures, which provide relief from deprivation; preventive measures, designed to prevent deprivation; promotive measures, aimed at enhancing income and capabilities; and transformative measures, which seek to address concerns of social justice and exclusion (Devereux and SabatesWheeler 2004).

The DFID Social Transfer Practice Paper identifies social transfers as an important option in addressing inequality, emphasising use of national social protection policy processes where possible (DFID 2005a). DFID's White Paper III classifies social protection as one of the four essential public services. The 2005 Agriculture Policy Paper discusses how social protection can complement agricultural growth. It states that well-targeted and timed social protection programmes can support agricultural growth prospects by promoting risk-taking activities and allowing households to cope with unexpected shocks and stresses. 


\subsection{Disaster risk reduction (DRR)}

DRR describes the development and application of policies, strategies and practices that minimise vulnerabilities, hazards and unfolding disaster impacts throughout a society in the broad context of sustainable development.

Disasters can have a huge impact on livelihood opportunities and on people's ability to cope with further stresses. Impacts such as loss of assets can lead to increased vulnerability of poor people and a 'downward spiral of deepening poverty and increasing risk' (PLOW 2007). DRR aims to make livelihoods more resilient to the impacts of disasters, hazards and shocks before the event.

In agriculture, DRR programmes have been used to lessen the effects of persistent food shortages and prevent widespread famines. Programmes include early warning systems, infrastructure investment, social protection measures, risk awareness and assessment, education and training, and environmental management.

DFID's White Paper III reiterates the linkage between DRR and climate change, describing DRR as a crucial part of adaptation (DFID 2006b). The policy paper Reducing the Risk of Disasters (DFID 2006a) recognises that about two-thirds of disasters are caused by climatic hazards, including drought, floods and typhoons, and that absolute levels of disaster risk are increasing due to various pressures including climate change. DFID's DRR approach supports improved international institutions that focus on reducing risk in the most disaster prone areas; on mainstreaming DRR into DFID's own programming and country-offices; and on supporting civil society and private sector engagement with vulnerable communities. International commitments to DRR have been strengthened through the Hyogo Framework for Action (HFA). One of its five priorities for action is to reduce underlying risk factors, including by integrating $D R R$ strategies with climate change adaptation.

\subsection{Climate change adaptation}

Adaptation is about reducing the risks posed by climate change to people's lives and livelihoods.

The human impacts of climate change are not evenly distributed. Both IPCC and the Stern Review identify poorer developing countries as being especially vulnerable to climate change because of their geographic exposure, low incomes and greater reliance on climate sensitive sectors, particularly agriculture. This in turn poses multiple threats to economic growth, poverty reduction, and the achievement of the Millennium Development Goals in developing countries (ADB et al. 2003; Stern 2006; IPCC 2007).

In the face of these challenges, a growing body of theory and practice has developed around adaptation to prepare for and respond to climate change. Adaptation is 'The ability to respond and adjust to actual or potential impacts of 
changing climate conditions in ways that moderate harm or take advantage of any positive opportunities that the climate may afford' (ADB et al. 2003). Put simply by DFID's White Paper III, 'Adaptation is about reducing the risks posed by climate change to people's lives and livelihoods' (DFID 2006b). Adaptation shares much in common with DRR in preventing harmful impact from extreme events. Climate change adds additional challenges to existing historic weather-related shocks, including more severe drought impacts, heat waves, and accelerated glacier retreat, hurricane intensity, and sea level rise (Adger et al. 2007).

While climate-related risks have always been intrinsic to natural resource-based livelihoods, global processes and crises are changing and deepening risks faced by poor, vulnerable people in rural areas, particularly those involved in agriculture. Changes in temperature, increasing rainfall variability, increases in frequency and intensity of extreme weather events associated with climate change, are likely to change food production potential in many parts of the world. There is also potential for knock-on effects to disrupt food distribution systems and change purchasing power of all those who are hit hardest.

As a sector with significant sensitivity to changes in climate-related shocks, agriculture has been heavily engaged in adaptation efforts, both through scientific approaches based on impacts modelling, and vulnerability approaches grounded in meeting immediate needs and resilience building (Tanner and Mitchell 2008a, 2008b). There is still considerable uncertainty around the impacts on agriculture, and implications for food accessibility and food supply stability (FAO 2005). One study suggests that the distributional effects overall will be negative for developing countries. Extreme events, such as increased frequency and intensity of droughts 'will have much more serious consequences for chronic and transitory food insecurity than will shifts in the patterns of average temperature and precipitation' (FAO 2005: 2).

\section{Conceptual linkages: parallels and differences}

\subsection{Why the limited links to date?}

Social Protection, DRR and Climate Adaptation seemingly have mutual measures and broad objectives. They all seek to mitigate risks faced by poor people. They tackle the impact of, and seek to build resilience against, shocks and stresses on livelihoods. They are also all in relatively formative stages of development and testing, rather than established components of development and poverty reduction.

While there are increasing efforts to link DRR and CCA approaches in the field and across international frameworks (Sperling and Szekely 2005; DFID 2007), links between either DRR or CCA and social protection have been more limited, possibly because: 
- Social protection is relatively new as a conceptual framework and discourse, even though many measures such as safety nets and starter packs have considerable history.

- Voices in the richer nations have dominated the adaptation debate, traditionally tending to emphasise climate extremes, disaster prevention and early warning systems, rather than a livelihoods approach to vulnerability (Richards 2003).

- The adaptation, DRR and social protection literatures have their origins in different academic traditions stemming from environment, humanitarian, and the social development/food security/livelihoods traditions. This has affected the creation of different concepts, terminology, institutional setting, objectives and instruments (see Annex for a summary).

- Capacity concerns, particularly among policymakers, lead to perceptions that linking social protection to DRR and adaptation is beyond the capability of the current system.

Table 3.1 highlights key features of these three policy areas. Despite the limited cross-fertilisation to date, it is possible to identify a set of linkages in the debates and conceptual frameworks that address a number of gaps evident when they are examined in isolation. Following an outline of these linkages below, Section 4 explores how they play out in practice in the context of agriculture.

\section{Table 3.1 Key characteristics of social protection, adaptation and DRR}

\begin{tabular}{|c|c|c|c|}
\hline & Social protection & Adaptation & DRR \\
\hline $\begin{array}{l}\text { Core disciplinary } \\
\text { grounding }\end{array}$ & $\begin{array}{l}\text { Development and } \\
\text { welfare economics }\end{array}$ & $\begin{array}{l}\text { Social development } \\
\text { and physical } \\
\text { sciences }\end{array}$ & $\begin{array}{l}\text { Physical sciences } \\
\text { and social } \\
\text { development }\end{array}$ \\
\hline Dominant focus & $\begin{array}{l}\text { Implementation of } \\
\text { measures to manage } \\
\text { risk }\end{array}$ & $\begin{array}{l}\text { Enabling processes } \\
\text { of adaptation }\end{array}$ & $\begin{array}{l}\text { Prevention of } \\
\text { disaster events and } \\
\text { preparedness to } \\
\text { respond }\end{array}$ \\
\hline $\begin{array}{l}\text { Main shocks and } \\
\text { stresses addressed }\end{array}$ & $\begin{array}{l}\text { Multiple - } \\
\text { idiosyncratic and } \\
\text { covariant }\end{array}$ & Climate-related & $\begin{array}{l}\text { All natural hazard- } \\
\text { related, including } \\
\text { climate and } \\
\text { geophysical }\end{array}$ \\
\hline $\begin{array}{l}\text { International } \\
\text { coordination }\end{array}$ & $\begin{array}{l}\text { Informal, OECD task } \\
\text { group }\end{array}$ & $\begin{array}{l}\text { UNFCCC - Nairobi } \\
\text { Work Programme }\end{array}$ & $\begin{array}{l}\text { UN-ISDR Hyogo } \\
\text { Framework for Action }\end{array}$ \\
\hline Main funding & $\begin{array}{l}\text { Ad hoc multilateral } \\
\text { and bilateral, NGOs, } \\
\text { national, CBOs and } \\
\text { FBOs }\end{array}$ & $\begin{array}{l}\text { Coordinated inter- } \\
\text { national funds: Global } \\
\text { Environment Facility, } \\
\text { UNFCCC/Kyoto } \\
\text { Protocol funds. Ad hoc } \\
\text { bilateral }\end{array}$ & $\begin{array}{l}\text { Coordinated interna- } \\
\text { tional funding: ISDR, } \\
\text { GFDRR, UNDP, Red } \\
\text { Cross, ad hoc civil } \\
\text { sponsored and bilateral }\end{array}$ \\
\hline
\end{tabular}




\subsection{Towards transformative and adaptive approaches through social protection}

The dominant safety net policy agenda developed during the 1980s and 1990s focused on addressing protection measures for transitory, shock-induced poverty. Two important elements remain prominent: a focus on the poorest sections of society, typically children, the disabled and the elderly, and in some cases the bottom 10 per cent of the population, and the transfer of resources (especially cash) to households to smooth consumption or support income.

Similarly, in the disasters field, the bulk of efforts and resources have been within relief and recovery designed to smooth the social impact of shocks. Despite renewed momentum and commitments, far less emphasis has been placed on preventative approaches associated with DRR that tackle disasters from a holistic perspective. In the adaptation field, attention to building on existing coping practices is also focused on smoothing shocks as a first step. However, without tackling structural factors permitting adaptive shifts in livelihood strategies that reduce vulnerability to future climate shocks and stresses, this could act to entrench current conditions.

Joining these related agendas in the agriculture context therefore means looking beyond simply protecting the most vulnerable to the impact of shocks and stresses, and towards prevention and promotion to address structural constraints around poverty. Table 3.2 highlights potential adaptation benefits of different strands of social protection. Social protection has much to offer in helping the poorest reduce their exposure to current (DRR) and future (adaptation) climate shocks.

\section{Table 3.2 Promoting adaptation through social protection}

\begin{tabular}{|l|l|l|}
\hline \multicolumn{1}{|c|}{ SP category } & \multicolumn{1}{|c|}{ SP instruments } & \multicolumn{1}{c|}{ Adaptation and DRR benefits } \\
\hline $\begin{array}{l}\text { Provision } \\
\text { (coping strategies) }\end{array}$ & $\begin{array}{l}\text { - social service provision } \\
\text { - basic social transfers (food/cash) } \\
\text { - pension schemes } \\
- \text { public works programmes }\end{array}$ & $\begin{array}{l}\text { - protection of those most } \\
\text { vulnerable to climate risks, with low } \\
\text { levels of adaptive capacity }\end{array}$ \\
\hline $\begin{array}{l}\text { Preventive } \\
\text { (coping strategies) }\end{array}$ & $\begin{array}{l}\text { - social transfers } \\
\text { - livelihood diversification } \\
\text { - weather-indexed crop insurance }\end{array}$ & $\begin{array}{l}\text { - prevents damaging coping } \\
\text { strategies as a result of risks to } \\
\text { weather-dependent livelihoods }\end{array}$ \\
\hline $\begin{array}{l}\text { Promotive } \\
\text { (building adaptive } \\
\text { capacity) }\end{array}$ & $\begin{array}{l}\text { - social transfers } \\
- \text { access to credit } \\
\text { - asset transfers/protection } \\
\text { - starter packs (drought/flood- } \\
\text { resistant) } \\
\text { - access to common property } \\
\text { resources } \\
- \text { public works programmes }\end{array}$ & $\begin{array}{l}\text { - promotes resilience through } \\
\text { livelihood diversification and security } \\
\text { to withstand climate related shocks } \\
\text { - promotes opportunities arising } \\
\text { from climate change }\end{array}$ \\
\hline $\begin{array}{l}\text { Transformative } \\
\text { (building adaptive } \\
\text { capacity) }\end{array}$ & $\begin{array}{l}\text { - promotion of minority rights } \\
\text { - anti-discrimination campaigns } \\
- \text { social funds }\end{array}$ & $\begin{array}{l}\text { - transforms social relations to } \\
\text { combat discrimination underlying } \\
\text { social and political vulnerability }\end{array}$ \\
\hline
\end{tabular}




\subsection{Timeframe and limits: driving longer term perspectives on social protection}

Many social protection interventions are planned over relatively short timeframes. More recent social protection policies and programmes refer to the need for 'longterm' interventions. Nevertheless, how this will be achieved, and analysis of how long-term they need to be to achieve stated objectives, is rarely fully considered. Considering adaptation and DRR in the context of social protection provides a strong incentive for developing longer term perspectives.

Climate change highlights the importance of considering how prevailing and future trends in weather and climate might affect the effectiveness of social protection measures, as well as how they might contribute to reducing vulnerability to shocks and stresses caused by today's climate. Linking with agendas on DRR and adaptation exposes social protection to fundamental issues around the ability of agricultural practice to support productive livelihoods in a changing climate (Dinar 2007).

Social protection and DRR measures designed to limit damages from shocks and stresses may simply not be sufficient in the longer term. For social protection to be resilient to climate change impacts, it needs to consider reducing dependence on climate sensitive livelihood activities. This raises questions of structural change, particularly centring on the existence and identification of 'limits to adaptation', beyond which in situ efforts will not reduce risk to acceptable levels.

While difficult to define with precision, the 'limits to adaptation' debate prompts social protection to refocus on more transformative approaches in areas where climate stresses are already, or are projected to become, severe constraints to supporting productive agriculture-based livelihoods (for example in severely drought-prone areas or river deltas). There undoubtedly remains a need for significant additional investment in agriculture to enhance resilience, promote growth and seize opportunities from more favourable climatic conditions and climate change-related revenue streams. However, addressing rural poverty reduction in the context of climate change is also likely to include promotion of offfarm rural enterprise and industry, urban services investment, assisted migration and improved remittance schemes.

\subsection{People-centred and social aspects}

The social protection agenda based on a dominant safety-net risk management approach has tended to focus on economic aspects of protection, in part a legacy of the World Bank's risk management framework. There is a consequent danger that by focusing on economic mechanisms rather than development objectives, social protection interventions have not fully addressed issues of social vulnerability including marginalisation and exclusion. In addition, many social protection policies and programmes have minimal dialogue with intended beneficiaries. This hinders development of programmes and policies that are based on the realities of the poor, considering both the constraints and opportunities they face. Voice is critical in the process of identifying needs and priorities and translating this into policy and resource commitments. 
Social aspects of vulnerability, disaster risk reduction and adaptation have similarly challenged the dominance of physical science disciplines that have not engaged extensively with social development agendas. Within adaptation, this dominance is reflected in the definition and conceptualisation of vulnerability as the residual effect of a given climate impact after any adaptation activities are undertaken, rather than the dynamic set of initial conditions that help determine the impact of a given shock or stress (O'Brien et al. 2004). The former conceptualisation has tended to favour technical issues in analysis and development of adaptation solutions, such as weather forecasting, flood protection infrastructure, new crop varieties, and irrigation in the agriculture sector (Klein et al. 2007).

Nevertheless, recent disasters and adaptation discourse and practice have started to take a more people-centred approach. This is evident in the greater attention being paid to social and institutional aspects in adaptive capacity, in the growing focus on community-based adaptation, and in the development of tools and methods to assess human vulnerability (Adger 1999; Wisner et al. 2004; Huq 2007; IFRC 1999; Chiwaka 2005).

\subsection{Institutional capacity and coordination}

The three fields also share a need to link policy and actions with wider aspects of human development and economic growth. If social protection is to produce positive social and economic outcomes, synergies need to be made with other disciplines that address the multiple dimensions of poverty. This differentiation is played out at multiple levels, including in development cooperation agencies such as the World Bank and DFID. At country level, social protection policies are often implemented in isolation, not within poverty reduction frameworks or growth strategies.

Ministries responsible for implementation (e.g. Ministries of social welfare) are commonly poorly resourced and marginalised and are poorly placed to provide the necessary links. Adaptation has suffered similar marginalisation in policy processes due to the common location of climate change focal points across the world in meteorological and environment ministries (Mitchell et al. 2006). Equally DRR is often found in response or disaster management agencies, rather than as part of development or mainstream politics. This has frustrated the cross-sectoral links necessary for work in key areas such as agriculture as these focal point ministries tend to be poorly resourced and relatively weak within the government system.

\subsection{Instrumentalism vs rights based approaches}

Social protection advocates have been divided into two distinct approaches by Devereux and Sabates-Wheeler (2007). The first approach is underpinned by instrumentalist arguments which see social protection as a temporary stopgap, compensating people for incomplete or missing insurance until the market prevails. 
Within adaptation and development fields a similar rationale can be identified in risk management based approaches, particularly in the context of development cooperation (Burton and Van Aalst 2004; Tanner et al. 2007). These stress fiduciary risks management to ensure that development finance is effective in meeting poverty reduction targets. DRR has witnessed a parallel growth in economic evaluation (DFID/ERM 2006). Risk reduction and adaptation are therefore a means to an end, and economic analysis builds the evidence base to advocate for DRR and adaptation as cost-effective means of preventing future negative impacts on development investments (Stern 2006).

The activist arguments underpinning social protection as an inviolable right to combat social injustice and inequality also have parallels with climate change debates. Social protection rationale is informed by the ideal of a guaranteed 'universal social minimum' based on citizenship rather than philanthropy or selfinterest (Devereux and Sabates-Wheeler 2007). Approaches to adaptation reflect these arguments. Here, adaptation in poor communities is regarded as a necessary response to a problem caused by richer people globally but with impacts felt most severely by poorer citizens who have contributed least to the problem (Paavola and Adger 2006). These equity and justice debates have formed the backbone of adaptation as an advocacy and campaigns issue, particularly among international NGOs (Simms et al. 2004; Christian Aid 2006; Polack 2008).

A key implication for designing and implementing social protection in the context of extreme events and climate change is therefore likely to be an enhanced engagement with rights and equity based arguments around climate change injustice (Tanner and Mitchell 2008a). How these arguments play out with prevailing instrumentalist approaches in the major donors, and particularly the World Bank, is likely to be crucial in defining the role of social protection in reducing disaster and climate risks.

\section{Linkages in practice: investigating the evidence base}

Increased variability in weather-related shocks and stresses, resulting from climate change, increases the risk of production failure for farmers particularly those engaged in rain-fed agriculture (IPCC 2007). This section reviews lessons from four different social protection measures aimed at the agriculture sector in the context of climate change adaptation and DRR. The instruments explored include: weather-indexed crop insurance, asset transfers, input distribution and seed fairs, and cash transfers. While not an exhaustive list, these instruments represent areas where social protection instruments related to adaptation and disasters are more developed. Country experiences from Bangladesh, Ethiopia, India, Kenya and Malawi reveal how these measures can enhance the resilience of vulnerable communities and point to ways in which social protection measures could be more resilient to current and future climate related shocks.

Further detail for each of these practical examples is shown in Annex. 


\subsection{Weather-indexed crop insurance}

Crop insurance is widespread throughout the developed world and commonly insures farmers against losses in crop yields resulting from weather-related stresses. As climate impacts become increasingly critical to agriculture production in developing countries due to climate change, insurance is likely to play a greater role in absorbing shocks and spreading risk. Transferring the model of loss-based insurance has been problematic however due to high transactions costs to verify losses, moral hazard that inhibits risk taking, and adverse selection of crops due to an expectation of payout in bad years (Morduch 2006; Hellmuth et al. 2007; Hess and Syroka 2005).

As a consequence, there has been a shift away from insuring against poor crop yields toward insuring against adverse weather. Weather-indexed crop insurance develops a contract written against a weather index, ideally based on historical records of the relationship between drought and crop failure. Farmers collect immediate insurance compensation if the index reaches a certain point or 'trigger', regardless of actual losses.

The pilot project undertaken by the Government of Malawi, the World Bank, International Research Institute for Climate and Society (IRI) and the National Smallholder Farmers Association of Malawi (NASFAM) provides empirical evidence of the use of weather-indexed crop insurance for groundnut production in a climate change context. Through the scheme, farmers entered into a loan agreement with an interest rate that includes a weather insurance premium. The loan enabled households to access an input package which included improved groundnut seed. In the event of a severe drought (as measured by the rainfall index), the borrower would pay only a fraction of the loan due, while the rest is paid by the insurer directly to the lender. The insurance guarantee against the loan allows high-risk and low-income farmers to obtain credit to invest in seeds and other inputs for higher yielding crops (Hellmuth et al. 2007).

In India, a local microfinance institution, BASIX, and an insurance company, ICICI Lombard along with the Commodity Risk Management Group and the World Bank have pioneered a rainfall insurance scheme in Andhra Pradesh. Similar to the Malawian scheme, the contracts ensured a prompt payout when rain falls below a crop-specific rainfall index. ICICI Lombard underwrote the insurance polices and reinsured the risks with an international reinsurance company. Individual farmers and self-help groups articulated product satisfaction in all of the pilot areas. Prompt settlement of claims in 2004 won the appreciation of the farmers who expressed their willingness in becoming repeat customers in 2005 (Manuamorn 2005).

The weather indexed approach guards against problems of adverse selection and moral hazard because regardless of whether the insurance is paid out or not, farmers still have an incentive to make productive management decisions (Hellmuth et al. 2007; Hess and Syroka 2005). The timeliness of payouts means that farmers are not forced to adopt costly coping strategies, such as the sale of productive assets, and are able to smooth their consumption by providing liquidity following crop losses (Morduch 2006). Where well designed, they may also permit farmers to enhance adaptive capacity through greater risk taking experimentation 
in agriculture practices that was not possible in crop-insurance schemes. As insured households and farms are more creditworthy, insurance can also promote investments in productive assets and higher-risk/higher-yield crops (Mechler et al. 2006).

Despite these advances, key challenges facing the expansion of weather-indexed insurance in light of climate change include (Mechler et al. 2006; Hellmuth et al. 2007; Holmes et al. 2007):

- Difficulties in targeting those most vulnerable to drought and food insecurity, engaged in non-commercial marginal agriculture;

- Failure to tackle differentiated gender impacts;

- High premiums may preclude involvement of very poor groups, who often live in areas of high climate risk;

- Capital costs such as the construction of weather stations must be funded by either the public or private sector to ensure broad coverage;

- Climate change presents significant uncertainty in predicting long-term weather patterns making it difficult to accurately assess financial risk;

- Increased climatic variability and occurrence of extreme events may result in larger and/or more frequent insurance payouts resulting in the possible insolvency of the insurance provider or higher premiums from re-insurers which may be inaccessible to the poor.

Climate change impacts provide an imperative to such schemes to integrate flexible and inclusive measures designed to consider differentiated nature of agriculture production among different groups of farmers, including poorer and more marginal farmers.

\subsection{Asset restocking}

The sale of productive assets is a common coping strategy among the rural poor during times of climatic stress or shock, placing the poor at risk of poverty and food insecurity (Sen 1981). Asset-building is therefore gaining prominence as a means of reducing risk and vulnerability, and smoothing the impact of shocks, including those related to the climate. This is a broad area of social protection measures that can include unconditional and conditional cash transfers, microcredit, and the direct provision of goods, services, or animals. It is often characterised by direct subsidy to the asset building strategy.

Three examples of asset transfer programmes from Bangladesh demonstrate vulnerability reduction of poor people. The Bangladesh Rural Advancement Committee's (BRAC) 'Challenging the Frontiers of Poverty Reduction: Targeting the Ultra Poor' (CFPR/TUP) programme provides households productive assets suitable for income-generating activities, a 'subsistence allowance' for 18 months, access to health and legal services, as well as social linkages with village elites. The Chars Livelihood Programme (CLP), another DFID supported project involves asset transfers to target extreme poverty in the Brahmaputra Chars area in 
northern Bangladesh. This has included more climate-resilient activities that facilitate mobility.

CLP demonstrates considerable success in average returns on assets and contributing to income diversification, but also problems in ensuring that assets transferred were well suited to local conditions (Marks 2007; Devereux and CollBlack 2007). In order to ensure that such programmes help to diversify income and buffer households from climatic risk, guidelines for Asset Transfer Implementation Guidelines for the CLP will need to ensure appropriate asset selection in the context of climate change (Tanner et al. 2007).

Another project, Reducing Vulnerability to Climate Change (RVCC) included alternative livelihoods promotion and asset transfer such as promoting livestock and birds that are more suited to the changing environmental conditions, particularly those that consume a low amount of fresh water and are capable of absorbing heat and temperature. Other examples include 'nucleus herds' for Masaai pastoralists in northern Kenya supported by Practical Action in the face of increasing incidents of drought. The most healthy and resilient females, and one or two males, were selected for 'seed stock' which were then isolated and provided with veterinary services and access to water and fodder. These nucleus herds have allowed households to rebuild assets stocks following the prolonged drought.

These examples demonstrate that asset transfer can contribute to reducing vulnerability to climate shocks, buffering climate related shocks at the household level by providing liquidity and alternative sources of income. Evidence suggests that they can operate simply and effectively as part of ongoing livelihood strengthening programmes. They may also be more suitable to target the very poorest and most vulnerable groups. Limited engagement of livelihoods programmes to date suggests there may be greater potential for integration of climate shocks and future climate change such that the selection of such assets considers the changing environmental context to ensure that schemes enhance rather than undermine resilience.

\subsection{Starter packs and seed fairs}

In response to calls to develop and distribute crop varieties that are drought and saline resistant, programmes for distribution of free inputs or inputs-for-work have become increasingly popular, especially across Africa. Input distribution has been a common response amongst development agencies in response to production failure resulting from drought and enhancing access to seeds and fertiliser. The distribution of fertiliser and seeds for free is intended to enhance food security by boosting food production among farmers who are unable to obtain such inputs. Malawi has had numerous manifestations of free input and input-for-work programmes, which have been strongly supported by DFID (Devereux et al. 2006a). Recent evaluation of starter pack programmes reveal success in boosting food production at the national level and household level food security (Devereux and Coll-Black 2007). 
While popular among donors, critics argue that inputs sourced through commercial seed and fertiliser companies are often inappropriate to local cropping patterns and agro-ecological conditions, can potentially distort local seed markets, and reduce crop diversity. Other critics of input distribution argue that such measures misdiagnose the inaccessibility of inputs with unavailability, and fail to assist in keeping seeds stocks year on year (Barahona and Cromwell 2005; Orindi and Ochieng 2005; Thompson et al. 2007; Devereux and Coll-Black 2007).

As an alternative to traditional input distribution programmes, DFID supported the Catholic Relief Services, the Food and Agriculture Organisation (FAO) and other local partners to implement a seed voucher and fair programme in Kenya's semiarid region in response to prolonged drought. Farmers were encouraged to bring their surplus seeds to fair sites where voucher holders were able to select seeds of their choice. On completion of the seed fair, seed retailers redeemed their vouchers for cash.

In contrast to the package of inputs approach which risks undermining biological diversity and leads to mono-cropping, seed vouchers and fairs have encouraged farmers to maintain crop diversity on their farms, contributing socio-ecological resilience. SV\&Fs programmes have been found to be substantially more cost-effective than traditional input distribution approaches, as well as providing an opportunity for greater information sharing among farmers (Orindi and Ochieng 2005).

Other examples include a Practical Action supported pilot in post-tsunami areas of Sri Lanka to trial 10 traditional saline-resistant varieties which had been present before the introduction of higher yielding varieties. These help increase resilience in light of sea-level rises in low lying areas. The RVCC programme in Bangladesh has similarly encouraged the planting of saline tolerant non-rice crops such as maize and grass during seasons when rice cannot be grown, increasing soil nutrient levels and providing fodder for cattle.

Input programmes need to be considered carefully as they have the potential to both reduce and exacerbate climate risks. Traditional input transfer programmes may be a tempting method to distribute drought- or saline-tolerant crop varieties; however, such programmes can undercut local seed markets and ignore indigenous knowledge. Furthermore, such free input distribution may in fact increase vulnerability to climate change by ignoring particular agro-ecological contexts and undermining crop diversity. On the other hand, seed voucher and fair projects present a cost-effective way to assist post-disaster recovery and enhance resilience by promoting crop diversity and information sharing between farmers.

\subsection{Cash transfers}

Cash transfer programmes are gaining momentum both in humanitarian relief efforts (Harvey 2005) and as an overall poverty reduction strategy (see Barrientos 2006). DFID is currently supporting a number of cash transfer programmes or pilots in Bangladesh, Ethiopia, Kenya, Malawi, Pakistan and Zambia (SabatesWheeler et al. 2007b). Redistributive cash transfers help raise incomes and smooth the consumption of the poor, allowing them to engage in moderate 
risk-taking, and to protect rather than erode their asset holdings when confronted by livelihood shocks (Devereux and Sabates-Wheeler 2004). Furthermore, cash transfer programmes may contribute to asset-building as well as the generation of economic multiplier effects, through the generation of local employment (GTZ 2005; Mattinen and Ogden 2006; Slater et al. 2006; DFID 2004; Devereux 2006).

Climate change is projected to increase stress on livelihoods (ADB et al. 2003). Predictable cash transfers could therefore play an important role in mitigating the vulnerability of the chronic poor who will increasingly be exposed to climate related shocks and stresses. Preliminary lessons form Ethiopia's Productive Safety Net Programme (PSNP) reveal a positive effect on household food consumption as well as the protection of household assets (Devereux et al. 2006b; Slater et al. 2006; Vaitla 2006). The PSNP contributed to a reduction in 'distress selling' of assets, provided an opportunity for households to create assets, and contributed positive impacts on human capital through increased school enrolment and access to health services (Slater et al. 2006).

However, evaluation reports also indicate that due to variations in food prices, the purchasing power of the PSNP transfer varied by more than 100 per cent across regions and seasons in 2005/06 (Devereux et al. 2006b). In general, the cash transferred was found to be too small and too unpredictable to protect poor households against hunger and food rationing in 2005, which has led to a shift in preference away from cash toward food (Pelham and Assegid 2006). Delays in implementation also mean that the PSNP was poorly timed and did not coincide with the peak hunger season. These problems were further compounded by late and erratic payment of cash and food transfers and budget constraints, which resulted in smaller transfers per beneficiary (Devereux and Coll-Black 2007).

Proactive safety nets in the form of cash transfers present a viable alternative to traditional post-disaster relief responses. Tanner and Mitchell (2008a) argue that in a changing climate, cash transfers and other social protection measures must reduce risk over extended timeframes, particularly in ecological and social environments subjected to high states of flux. Repeated transfers at predictable and regular intervals allow recipients to spread risk and to plan spending and investment behaviour over longer timeframes. Larger and continuous cash provisions are more likely to lead to asset accumulation and poverty reduction (and therefore risk reduction) than occasional or erratic transfers (Devereux and Coll-Black 2007; Marcus 2007). Access to contingency funds or savings may be an effective way to spread risk over time (Tanner and Mitchell 2008b). With regard to the PSNP, emerging evidence also suggests that cash transfers may contribute to the formation of informal savings groups.

Conditional cash transfers public works programmes may also contribute to adaptation and DRR through the construction of community assets that enhance resilience. Examples in Ethiopia of roads, water catchments and soil conservation activities have increased access to local markets, health facilities and water as well as greater soil fertility and flood mitigation (Guenther 2007).

Common critiques of such programmes include overstated economic benefits and rapid deterioration of assets following completion of the scheme (McCord 2005; Devereux 2002). Moreover, conditional cash transfers work against the principle 
that social protection should be viewed as a basic right (DFID 2004; Devereux and Coll-Black 2007). Limited information exists within existing programmes to assess the full cost-effectiveness of social transfers (Devereux et al. 2005; Devereux and Coll-Black 2007), although evidence does suggest that concerns about unaffordability are overstated, with predictable social transfers shown to be more cost-effective than food aid (Devereux and Coll-Black 2007; Harvey 2005). Similarly, there is little empirical evidence assessing the effectiveness of cash transfers that relate analysis to the changing frequency of climate-related hazards.

\subsection{Summary of lessons from case studies}

Key messages and lessons from case studies are synthesised in Table 4.1.

\section{Table 4.1 Benefits and challenges of social protection for adaptation and DRR}

\begin{tabular}{|c|c|c|}
\hline $\begin{array}{l}\text { Social protec- } \\
\text { tion measure }\end{array}$ & Benefits for adaptation and DRR & Challenges \\
\hline $\begin{array}{l}\text { Weather-based } \\
\text { crop insurance }\end{array}$ & $\begin{array}{l}\text { - Rapid payouts possible } \\
\text { - Guards against the adverse } \\
\text { selection and moral hazard } \\
\text { - Frees up assets for investment in } \\
\text { adaptive capacity } \\
\text { - Easily linked to trends and } \\
\text { projections for climate change } \\
\text { - Supports adaptive flexibility and } \\
\text { risk taking }\end{array}$ & $\begin{array}{l}\text { - Targeting marginal farmers } \\
\text { - Tackling differentiated gender } \\
\text { impacts } \\
\text { - Affordable premiums for poor } \\
\text { - Subsidising capital costs } \\
\text { - Integrating climate change projec- } \\
\text { tions into financial risk assessment } \\
\text { - Guarantee mechanisms for } \\
\text { re-insurance }\end{array}$ \\
\hline Seed transfer & $\begin{array}{l}\text { - Boost agricultural production and } \\
\text { household food security } \\
\text { - Post disaster response tool } \\
\text { - Seed varieties can be tailored to } \\
\text { changing local environmental } \\
\text { conditions } \\
\text { - Cost effectiveness of seed } \\
\text { voucher and fair projects } \\
\text { - Fairs promote crop diversity and } \\
\text { information sharing }\end{array}$ & $\begin{array}{l}\text { - Ensuring locally appropriate seed } \\
\text { and fertiliser varieties } \\
\text { - Protection of crop diversity } \\
\text { - Reduce distortion of local markets } \\
\text { - Focus on access rather than only } \\
\text { availability } \\
\text { - Inclusive approach that draws in } \\
\text { marginal farmers }\end{array}$ \\
\hline Asset transfer & $\begin{array}{l}\text { - Ability to target most vulnerable } \\
\text { people } \\
\text { - Easily integrated in livelihoods } \\
\text { programmes }\end{array}$ & $\begin{array}{l}\text { - Ensuring local appropriateness of } \\
\text { assets } \\
\text { - Integrating changing nature } \\
\text { environmental stresses in asset } \\
\text { selection }\end{array}$ \\
\hline Cash transfers & $\begin{array}{l}\text { - Targeting of most vulnerable to } \\
\text { climate shocks } \\
\text { - Smoothing consumption allowing } \\
\text { adaptive risk-taking and investment } \\
\text { - Flexibility enhanced to cope with } \\
\text { climate shocks }\end{array}$ & $\begin{array}{l}\text { - Ensuring adequate size and } \\
\text { predictability of transfers } \\
\text { - Long term focus to reduce risk } \\
\text { over extended timeframes } \\
\text { - Demonstrating economic case for } \\
\text { cash transfers related to climate } \\
\text { shocks } \\
\text { - Use of socio-ecological vulner- } \\
\text { ability indices for targeting }\end{array}$ \\
\hline
\end{tabular}




\section{Conclusions and recommendations}

\subsection{Developing 'adaptive social protection'}

This paper illustrates the links between social protection, climate change adaptation and DRR in the context of agriculture. We showed how current experiences of social protection have much to offer in protecting the poor to current (DRR) and future (adaptation) weather extremes. We also suggest ways in which social protection programmes themselves can be made more robust in the face of current and future shocks. This includes:

a) Climate proofing social protection through a long-term vision in the context of more reliable and accurate predictions and consideration of vulnerability.

b) Policy and programmatic options for climate change adaptation.

c) A preventative and holistic poverty approach for DRR.

d) An improved growth focus for agriculture.

These opportunities are suggested in bringing together the objectives of three distinctive areas of work within the context of agricultural growth (see Figure 5.1). This places social protection in the context of the influence of natural phenomena, and particularly climate, on agricultural productivity and related livelihoods. It aims to provide a framework for understanding how social protection measures may be tailored to become more resilient to risks from current disaster hazards and future climate-related impacts, including conditions that have not been experienced before.

Figure 5.1 Adaptive social protection

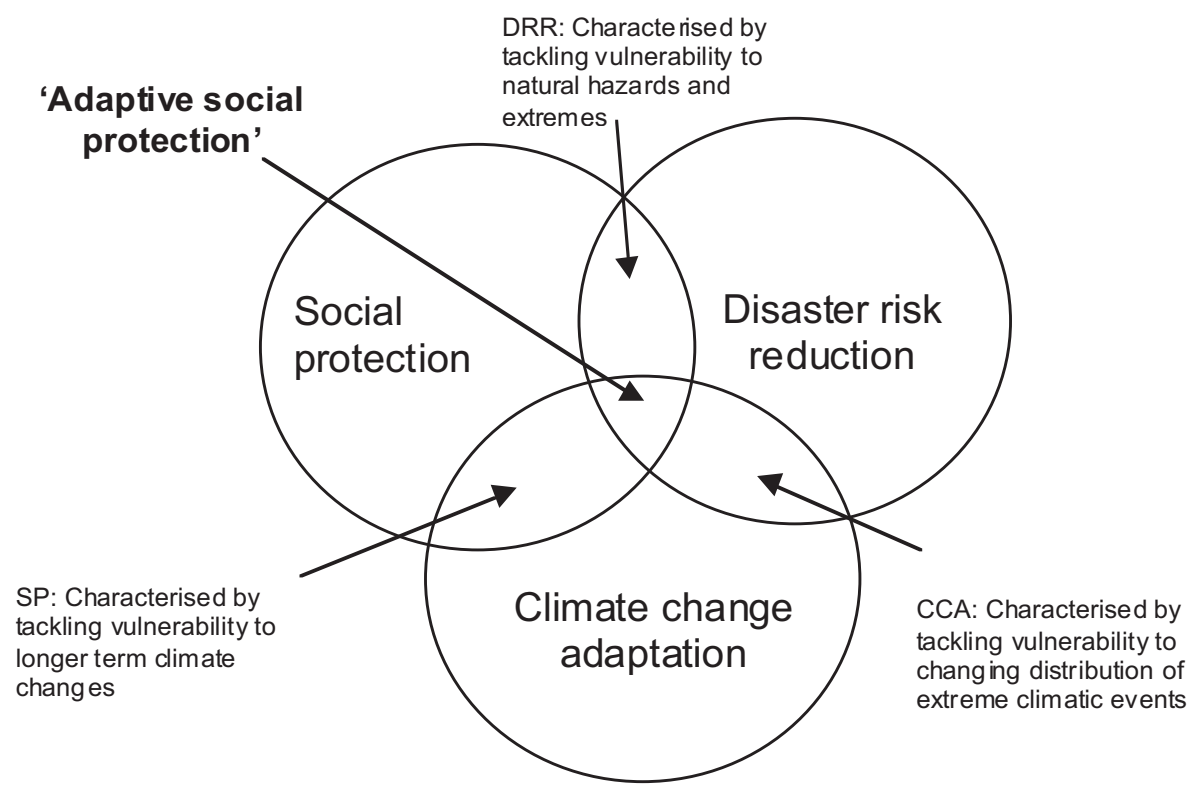


By placing social protection in the context of the impacts of natural phenomena particularly climate - on agricultural productivity and related livelihoods, we establish a framework for social protection measures that are resilient to disaster risks, and that acknowledge the changing nature of climate-related impacts including the future existence of conditions that have not been experienced before. This adaptive social protection is characterised by a number of features that include:

- An emphasis on transforming productive livelihoods as well as protecting, and adapting to changing climate conditions rather than simply reinforcing coping mechanisms.

- Grounding in an understanding of the structural root causes of poverty in a particular region or sector, permitting more effective targeting of vulnerability to multiple shocks and stresses.

- Incorporation of rights-based rationale for action that addresses social exclusion, stressing equity and justice dimensions of poverty and climate change adaptation in addition to instrumentalist rationale based primarily on economic efficiency.

- An enhanced role for research from both the natural and social sciences to inform the development and targeting of social protection policies and measures in the context of the burden of both geophysical hazards and changing climate-related hazards.

- A longer term perspective for social protection policies that takes into account the changing nature of shocks and stresses.

This is not to suggest that all DRR, adaptation and social protection work will, or indeed should, necessarily meet all of these characteristics. There are likely to still be roles for specific policies and instruments within each of the fields. However, this analysis does permit the identification of a number of potential areas for future work that links these related fields together.

\subsection{Recommendations for further areas of work}

There are likely to still be roles for specific policies and instruments within each of the fields. However, our analysis does permit the identification of a number of potential areas for future work that links these related fields together, and a number of ways to address the challenges of developing adaptive social protection in the broader context where agriculture is a part, but not the only, consideration. Preliminary recommendations for these opportunities and options are outlined in Table 5.2 . 


\section{Table 5.2 Opportunities and further requirements}

\begin{tabular}{|c|c|}
\hline Title & Issue \\
\hline $\begin{array}{l}\text { Collaboration } \\
\text { mechanisms }\end{array}$ & $\begin{array}{l}\text { Events } \\
\text { - Included discussion on linkages in major international conferences. } \\
\text { E.g. in the meetings of the UNFCC climate change negotiations held } \\
\text { during the run-up to the Copenhagen Conference of December } 2009 \\
\text { including Nairobi UNFCC work programme on the socioeconomics of } \\
\text { adaptation. } \\
\text { b Donor collaboration } \\
\text { - } \quad \text { DFID - World Bank collaboration on social dimensions of climate change } \\
\text { - } \quad \text { Dink to the National Adaptation Programme of Action } \\
\text { - } \quad \text { EU interest in linkages between social protection and climate change. }\end{array}$ \\
\hline $\begin{array}{l}\text { Improving } \\
\text { the evidence } \\
\text { base }\end{array}$ & $\begin{array}{l}\text { An evidence-based body of work examining how combining measures can } \\
\text { mitigate vulnerability. This could include: } \\
\text { - Capturing further lessons from existing case studies to support learning } \\
\text { in other countries* } \\
\text { Development of an index and categories } \\
\text { - How linkages support economic growth including evidence on the } \\
\text { economic costs and benefits of social protection measures } \\
\text { Evidence of cost effectiveness of social protection measures relative to } \\
\text { the alternative impacts } \\
\text { Combining the study of poverty impacts of climate shocks on households } \\
\text { or regions with trends and projections for future climate hazards. }\end{array}$ \\
\hline $\begin{array}{l}\text { Tools/ } \\
\text { resources }\end{array}$ & $\begin{array}{l}\text { - Climate Risk Assessments (CRA) are developed for use in conjunction } \\
\text { with proposed social protection programmes } \\
\text { How to link information screening and risk assessment processes. Can } \\
\text { climate screening be part of the risk assessment process to ensure that a } \\
\text { range of social protection options are part of the recommendation } \\
\text { following the risk assessment } \\
\text { Development of practical guides on the considerations necessary when } \\
\text { making the linkages between disciplines. }\end{array}$ \\
\hline $\begin{array}{l}\text { Capacity } \\
\text { building }\end{array}$ & $\begin{array}{l}\text { - Reading weeks and training programmes on linking disciplines (e.g. } \\
\text { UNICEF social protection training). }\end{array}$ \\
\hline Funding & $\begin{array}{l}\text { - Review existing adaptation funding guidelines and criteria and identify } \\
\text { how well social protection interventions are integrated into them } \\
\text { - Following the review, dialogue with existing adaptation funders on } \\
\text { potential to develop adaptive social protection further. }\end{array}$ \\
\hline $\begin{array}{l}\text { Dialogue } \\
\text { among } \\
\text { disciplines }\end{array}$ & $\begin{array}{l}\text { - Examine how climate science evidence can be used as an advocacy tool } \\
\text { for change } \\
\text { a GCOS looks at the impact of climate change on agriculture - GECAFS } \\
\text { project } \\
\text { b Discuss the findings of the ILRI-led report on climate change vulnerability } \\
\text { in Africa with social protection and food security specialists and examine } \\
\text { implications for their work } \\
\text { Incorporate dialogue into major agricultural forums and debates } \\
\text { a The Green Revolution and Millennium Project dialogue } \\
\text { b Rockefeller Foundation programme - advocating for linkages between } \\
\text { their climate change and agriculture programmes } \\
\text { c EC Global Climate Change Alliance as it develops } \\
\text { - DRR } \\
\text { a Improved seasonal forecasts and links with social protection enabling } \\
\text { b Social protection as a preventative measure around seasonal forecasting } \\
\text { Develop an inventory of social protection measures for DRR. }\end{array}$ \\
\hline
\end{tabular}




\section{Annex: Dimensions of social protection, DRR and climate change adaptation}

The matrix lays out the key definitions, concepts, objectives and policy instruments under Social Protection, Disaster Risk Reduction and Climate Change Adaptation approaches respectively, in the context of livelihoods, risk and vulnerability.

Table A1 Dimensions of social protection, DRR and climate change adaptation policies and approaches

\begin{tabular}{|c|c|c|c|}
\hline & SP & DRR & CCA \\
\hline Definition & $\begin{array}{l}\text { All initiatives that } \\
\text { transfer income or } \\
\text { assets to the poor, } \\
\text { protect the vulnerable } \\
\text { against livelihood } \\
\text { risks, and enhance } \\
\text { the social status and } \\
\text { rights of the } \\
\text { marginalised } \\
\text { (Devereux and } \\
\text { Sabates-Wheeler } \\
\text { 2004) }\end{array}$ & $\begin{array}{l}\text { The systematic } \\
\text { development and } \\
\text { application of } \\
\text { policies, strategies } \\
\text { and practices to } \\
\text { minimise } \\
\text { vulnerabilities, } \\
\text { hazards and the } \\
\text { unfolding of disaster } \\
\text { impacts throughout a } \\
\text { society, in the broad } \\
\text { context of sustainable } \\
\text { development (UNDP } \\
\text { 2004) }\end{array}$ & $\begin{array}{l}\text { The ability to } \\
\text { respond and adjust } \\
\text { to actual or potential } \\
\text { impacts of changing } \\
\text { climate conditions in } \\
\text { ways that moderate } \\
\text { harm or take } \\
\text { advantage of any } \\
\text { positive opportunities } \\
\text { that the climate may } \\
\text { afford (ADB et al. } \\
2003 \text { ) }\end{array}$ \\
\hline \multicolumn{4}{|l|}{ Concepts } \\
\hline Risk & $\begin{array}{l}\text { Risk inherent in } \\
\text { livelihoods activities/ } \\
\text { domestic life of } \\
\text { poorest people }\end{array}$ & $\begin{array}{l}\text { The probability of } \\
\text { harmful conse- } \\
\text { quences, or expected } \\
\text { loss of lives, people } \\
\text { injured, property, } \\
\text { livelihoods, economic } \\
\text { activity disrupted (or } \\
\text { environment } \\
\text { damaged) resulting } \\
\text { from interactions } \\
\text { between natural or } \\
\text { human induced } \\
\text { hazards and } \\
\text { vulnerable conditions. } \\
\text { Risk = Hazard x } \\
\text { Vulnerability (UNDP } \\
\text { 2004) } \\
\text { Tackling the under- } \\
\text { lying elements of risk } \\
\text { from natural and } \\
\text { technological hazards } \\
\text { ( DFID/PLOW n/d) }\end{array}$ & $\begin{array}{l}\text { Function of } \\
\text { probability and } \\
\text { magnitude of } \\
\text { different impacts } \\
\text { (IPCC 2001) }\end{array}$ \\
\hline Shocks & $\begin{array}{l}\text { Focus on both shocks } \\
\text { and stresses }\end{array}$ & Focus on shocks & $\begin{array}{l}\text { Focus on shocks } \\
\text { and stresses }\end{array}$ \\
\hline
\end{tabular}




\begin{tabular}{|c|c|c|c|}
\hline & SP & DRR & CCA \\
\hline Livelihoods & $\begin{array}{l}\text { Assets determine } \\
\text { how people can } \\
\text { respond to shocks } \\
\text { and stresses }\end{array}$ & $\begin{array}{l}\text { The means by which } \\
\text { an individual or house- } \\
\text { hold obtains assets } \\
\text { for survival and self } \\
\text { development. } \\
\text { Livelihood assets are } \\
\text { the tools (skills, } \\
\text { objects, rights, know- } \\
\text { ledge, social capital) } \\
\text { applied to enacting } \\
\text { the livelihood (UNDP } \\
\text { 2004) }\end{array}$ & \\
\hline Vulnerability & $\begin{array}{l}\text { Seen as a starting } \\
\text { point? Multi- } \\
\text { dimensional and } \\
\text { embedded within } \\
\text { economic, social and } \\
\text { political systems }\end{array}$ & $\begin{array}{l}\text { A human condition or } \\
\text { process resulting } \\
\text { from physical, social, } \\
\text { economic and } \\
\text { environmental factors, } \\
\text { which determine the } \\
\text { likelihood and scale } \\
\text { of damage from the } \\
\text { impact of a given } \\
\text { hazard (UNDP 2004) }\end{array}$ & $\begin{array}{l}\text { The degree to which } \\
\text { a system is } \\
\text { susceptible to, or } \\
\text { unable to cope } \\
\text { with, adverse effects } \\
\text { of climate change, } \\
\text { including climate } \\
\text { variability and } \\
\text { extremes. Vulnera- } \\
\text { bility is a function of } \\
\text { the character, } \\
\text { magnitude, and rate } \\
\text { of climate variation } \\
\text { to which a system is } \\
\text { exposed, its sen- } \\
\text { sitivity, and its } \\
\text { adaptive capacity } \\
\text { (IPCC 2001) }\end{array}$ \\
\hline Resilience & $\begin{array}{l}\text { Ability of individual/ } \\
\text { household/community } \\
\text { /system to withstand } \\
\text { change / capacity to } \\
\text { restore following } \\
\text { external shock }\end{array}$ & $\begin{array}{l}\text { The capacity of a } \\
\text { system, community } \\
\text { or society to resist or } \\
\text { to change in order } \\
\text { that it may obtain an } \\
\text { acceptable level in } \\
\text { functioning and } \\
\text { structure. This is } \\
\text { determined by the } \\
\text { degree to which the } \\
\text { social system is } \\
\text { capable of organising } \\
\text { itself, and the ability } \\
\text { to increase its } \\
\text { capacity for learning } \\
\text { and adaptation, } \\
\text { including the capacity } \\
\text { to recover from a } \\
\text { disaster (UNDP 2004) }\end{array}$ & $\begin{array}{l}\text { Amount of change a } \\
\text { system can undergo } \\
\text { without changing } \\
\text { state (IPCC 2001) } \\
\text { Social perspectives } \\
\text { critiques of this } \\
\text { natural science } \\
\text { perspective high- } \\
\text { light resilience as } \\
\text { the conditions that } \\
\text { enable social or } \\
\text { ecological system } \\
\text { to bounce back } \\
\text { after a shock } \\
\text { (Tompkins and } \\
\text { Adger 2004) }\end{array}$ \\
\hline $\begin{array}{l}\text { Coping/adaptive } \\
\text { capacity }\end{array}$ & & $\begin{array}{l}\text { The manner in which } \\
\text { people and organ- } \\
\text { isations use existing } \\
\text { resources to achieve } \\
\text { various beneficial } \\
\text { ends during unusual, } \\
\text { abnormal and adverse } \\
\text { conditions of a } \\
\text { disaster phenomenon } \\
\text { or process (UNDP } \\
2004 \text { ) }\end{array}$ & $\begin{array}{l}\text { Adaptation capacity } \\
\text { is the ability of a } \\
\text { system to adjust to } \\
\text { climate change } \\
\text { (including climate } \\
\text { variability and } \\
\text { extremes), to } \\
\text { moderate potential } \\
\text { damages, to take } \\
\text { advantage of } \\
\text { opportunities, or to } \\
\text { cope with the } \\
\text { consequences } \\
\text { (IPCC 2001) }\end{array}$ \\
\hline
\end{tabular}




\begin{tabular}{|c|c|c|c|}
\hline & SP & DRR & CCA \\
\hline \multicolumn{4}{|l|}{ Objectives } \\
\hline & $\begin{array}{l}\text { Reactive and pro- } \\
\text { active resilience- } \\
\text { building }\end{array}$ & $\begin{array}{l}\text { Tackle underlying } \\
\text { elements of risk from } \\
\text { natural and tech- } \\
\text { nological hazards. } \\
\text { Reduce vulnerability } \\
\text { of individuals, comm- } \\
\text { unities and societies, } \\
\text { and to build their } \\
\text { resilience or capacity } \\
\text { to prepare for and } \\
\text { withstand the impacts } \\
\text { of disasters. Integrate } \\
\text { disaster prepared- } \\
\text { ness and hazard } \\
\text { mitigation into longer- } \\
\text { term development. } \\
\text { Improve the capacity } \\
\text { of agencies mandated } \\
\text { with responding to } \\
\text { disaster events. } \\
\text { 'Disaster-proof' dev- } \\
\text { elopment processes } \\
\text { - ensure develop- } \\
\text { ment assistance takes } \\
\text { adequate account of } \\
\text { disaster risk, recog- } \\
\text { nising that reducing } \\
\text { all risk is in practical } \\
\text { terms unattainable } \\
\text { (DFID/PLOW n/d) }\end{array}$ & $\begin{array}{l}\text { Enable individuals } \\
\text { and communities to } \\
\text { adapt over the long } \\
\text { term to the impact } \\
\text { of current and } \\
\text { future climate } \\
\text { extremes and } \\
\text { surprises caused } \\
\text { by climate change }\end{array}$ \\
\hline \multicolumn{4}{|l|}{ Instruments } \\
\hline Policy & $\begin{array}{l}\text { - Cash transfers } \\
\text { - Crop insurance } \\
\text { - Price hedging } \\
\text { - Some emergency } \\
\text { responses eg } \\
\text { resettlement } \\
\text { - Stocking/restocking } \\
\text { - Input subsidy } \\
\text { - Microfinance } \\
\text { - Employment } \\
\text { schemes } \\
\text { - Food for work } \\
\text { - School feeding } \\
\text { - Pension schemes }\end{array}$ & $\begin{array}{l}\text { - Early warning } \\
\text { systems } \\
\text { - Investment in } \\
\text { sectoral programmes } \\
\text { - Donations } \\
\text { - Relocation }\end{array}$ & $\begin{array}{l}\text { Insurance: weather- } \\
\text { indexed, fishery, } \\
\text { climate, stocking/ } \\
\text { restocking, } \\
\text { education, training } \\
\text { and awareness of } \\
\text { climate change, } \\
\text { drought-resistant } \\
\text { seeds, better } \\
\text { coastal protection }\end{array}$ \\
\hline Implementation & $\begin{array}{l}\text { - National } \\
\text { - Localised pilots }\end{array}$ & $\begin{array}{l}\text { Applied both vertically } \\
\text { (from local level, com- } \\
\text { munity-based actions } \\
\text { to improving national } \\
\text { legislation) and hori- } \\
\text { zontally by addressing } \\
\text { risk across all major } \\
\text { developmental sectors } \\
\text { and by improving the } \\
\text { coordination and } \\
\text { communication bet- } \\
\text { ween government, } \\
\text { private sector and } \\
\text { civil society (DFID } \\
\text { PLOW n/d) }\end{array}$ & $\begin{array}{l}\text { Vertically through } \\
\text { integration in } \\
\text { mainstream } \\
\text { development } \\
\text { policies and } \\
\text { horizontally through } \\
\text { increasing adaptive } \\
\text { capacity in key } \\
\text { sectors, such as } \\
\text { agriculture and } \\
\text { health }\end{array}$ \\
\hline
\end{tabular}




\section{References}

Adger, W.N. (1999) 'Social Vulnerability to Climate Change and Extremes in Coastal Vietnam', World Development 27.2: 249-69

Adger, W.N.; Agrawala, S.; Mirza, M.M.Q.; Conde, C.; O’Brien, K.; Pulhin, J.; Pulwarty, R.; Smit, B. and Takahashi, K. (2007) 'Assessment of Adaptation Practices, Options, Constraints and Capacity,' in M.L. Parry, et al. (eds), Climate Change 2007: Impacts, Adaptation and Vulnerability. Contribution of Working Group II to the Fourth Assessment Report of the Intergovernmental Panel on Climate Change, Cambridge: Cambridge University Press: 717-43

African Development Bank; Asian Development Bank; Department for International Development: United Kingdom; Directorate-General for International Cooperation: the Netherlands; Directorate General for Development: European Commission; Federal Ministry for Economic Cooperation and Development: Germany; Organization for Economic Cooperation and Development; United Nations Development Programme; United Nations Environment Programme; World Bank (2003) Poverty and Climate Change: Reducing the Vulnerability of the Poor Through Adaptation, www.undp.org/energy/povcc.htm (accessed 8 July 2008)

Barahona, C. and Cromwell, E. (2005) 'Starter Pack and Sustainable Agriculture', in S. Levy (ed.), Starter Packs: A Strategy to Fight Hunger in Developing Countries? Lessons from the Malawi Experience 1998-2003, Wallingford: CABI Publishing

Barrientos, A. (2006) Social Assistance in Developing Countries Database, Version 2.0, Brighton: IDS

Burton, I. and van Aalst, M. (2004) Look Before You Leap: A Risk Management Approach for Incorporating Climate Change Adaptation in World Bank Operations, Washington DC: World Bank

Chiwaka, E. (2005) Mainstreaming Participatory Vulnerability Analysis in ActionAid International, Disaster Studies Working Paper 13, London: Benfield Hazard Research Centre

Christian Aid (2006) The Climate of Poverty: Facts, Fears and Hopes, www.christianaid.org.uk/Images/climate_of_poverty_tcm15-21613.pdf (accessed 30 October 2008)

Devereux, S. (2006) 'Cash Transfers and Social Protection,' paper prepared for the regional workshop on Cash Transfer Activities in Southern Africa, co-hosted by the Southern African Regional Poverty Network (SARPN), Regional Hunger and Vulnerability Programme (RHVP) and Oxfam GB, 9-10 October 2006, Johannesburg, South Africa

- (2002) From Workfare to Fair Work: The Contribution of Public Works and Other Labour-Based Infrastructure Programmes to Poverty Alleviation, Issues in Employment and Poverty Discussion Paper 5, Geneva: International Labour Office

Devereux, S. and Coll-Black, S. (2007) Review of Evidence and Evidence Gaps 
on the Effectiveness and Impacts of DFID-supported Pilot Social Transfer Schemes, DFID Social Transfers Evaluation, Brighton: IDS

Devereux, S. and Sabates-Wheeler, R. (2007) 'Editorial Introduction: Debating Social Protection', IDS Bulletin 38.3, May, Brighton: IDS

_ (2004) Transformative Social Protection, IDS Working Paper 232, Brighton: IDS

Devereux, S.; Marshall, J.; MacAskill, J. and Pelham, L. (2005) Making Cash Count: Lessons from Cash Transfer Schemes in East and Southern Africa for Supporting the Most Vulnerable Children and Households, London and Brighton: Helpage International, Save the Children UK and IDS

Devereux, S.; Baulch, B.; MacAuslan, I.; Phiri, A. and Sabates-Wheeler, R. (2006a) Vulnerability and Social Protection in Malawi, IDS Discussion Paper 387, Brighton: IDS

Devereux, S.; Sabates-Wheeler, R.; Tefera, M. and Taye, H. (2006b) Ethiopia's Productive Safety Net Programme: Trends in PSNP Transfers within Targeted Households, Brighton: IDS

DFID (2007) 'Links Between Climate Change Adaptation and Disaster Risk Reduction', DFID Briefing Note, Ti-Up consortium (draft in review)

_ (2006a) Reducing the Risk of Disasters - Helping to Achieve Sustainable Poverty Reduction in a Vulnerable World, DFID Policy Paper, March, London: Department for International Development

_ (2006b) Eliminating World Poverty: Making Governance Work for the Poor, White Paper on International Development, London: Department for International Development

- (2005a) Social Transfers and Chronic Poverty: Emerging Evidence and the Challenge Ahead, London: Department for International Development

- (2005b) Growth and Poverty Reduction: The Role of Agriculture, London: Department for International Development

(2004) Climate Change and Poverty Keysheet 1, www.dfid.gov.uk/pubs/files/ climatechange/1povertyPRS.pdf (accessed 8 July 2008)

DFID/ERM (2006) Natural Disaster and Disaster Risk Reduction Measures: A Desk Review of Costs and Benefits, London: Environmental Resources Management (ERM)

DFID/ PLOW (n/d) Disaster Risk Reduction Briefing Note, available at: www.passlivelihoods.org.uk/plow/default.asp?id=265 (accessed 10 July 2008)

Dinar, A. (2007) Climate Change: The Final Blow for Agriculture in Africa?, World Bank Research Brief, http://go.worldbank.org/JXY436ZJV0 (accessed 30 January 2009)

FAO (2005) Special Event on Impact of Climate Change, Pests and Diseases on Food Security and Poverty Reduction, Background Document for 31st Session of 
the Committee on World Food Security 23-26 May 2005

Farrington, J.; Slater, R. and Holmes, R. (2004a) Social Protection and Pro-poor Agricultural Growth: What Scope for Synergies?, Natural Resource Perspectives 91, London: Overseas Development Institute

_ (2004b) The Search for Synergies Between Social Protection and Livelihood Promotion: The Agriculture Case, ODI Working Paper 232, London: Overseas Development Institute

GTZ (2005) First Monitoring Report: Pilot Cash Transfer Scheme, Kalomo District, Zambia, Deutsche Gesellschaft für Technische Zusammenarbeit (GTZ) GmbH, available on the web http://mcdss.websitedesign.co.zm/media/68.external_monitoring_-_2nd_edition.pdf (accessed 30 January 2009)

Guenther, B. (2007) 'Cash-for-Work, Vulnerability and Social Resilience: A Case Study of the Productive Safety Net Programme in Sidama Zone, Ethiopia,' MPhil Dissertation, Brighton: IDS

Harvey, P. (2005) Cash and Vouchers in Emergencies, London: Overseas Development Institute

Hellmuth, M.E.; Moorhead, A.; Thomson, M.C. and Williams, J. (eds) (2007) Climate Risk Management in Africa: Learning from Practice, New York:

International Research Institute for Climate and Society (IRI), Columbia University Hess, U. and Syroka, J. (2005) Weather-based Insurance in Southern Africa: The Case of Malawi, Agriculture and Rural Development Discussion Paper 13, Washington: World Bank

Holmes, R.; Farrington, J. and Slater, R. (2007) 'Social Protection and Growth: The Case of Agriculture', IDS Bulletin 38.3: 95-100

Huq, S. (2007) Community-based Adaptation: An IIED Briefing, London: IIED IDS (2006) Looking at Social Protection Through a Livelihoods Lens, In Focus Series, Brighton: IDS

IFRC (1999) Vulnerability and Capacity Assessment: An International Federation Guide, Geneva: International Federation of Red Cross and Red Crescent Societies

IPCC (2007) Contribution of Working Group II to the Fourth Assessment Report of the Intergovernmental Panel on Climate Change: Impacts, Adaptation and Vulnerability Summary for Policymakers, available from: www.ipcc.ch/ipccreports/ar4-wg2.htm (accessed 30 October 2008)

- (2001) Summary for Policymakers: Climate Change 2001: Impacts, Adaptation, and Vulnerability, available from www.ipcc.ch/pdf/climate-changes2001/impact-adaptation-vulnerability/impact-spm-en.pdf (accessed 30 October 2008)

Klein R.J.T.; Eriksen S.E.H.; Næss L.O.; Hammill A.; Tanner T.M.; Robledo C. and O'Brien, K.L. (2007) 'Portfolio Screening to Support the Mainstreaming of 
Adaptation to Climate Change Into Development Assistance,' Climatic Change 84.1: $23-44$

Manuamorn, O. (2005) Scaling-Up Micro Insurance: The Case of Weather Insurance for Smallholders In India, Washington DC: World Bank

Marcus, R. (2007) Social Protection Transfers for Chronically Poor People, CPRC Policy Brief 2, Manchester: Chronic Poverty Research Centre

Marks, M. (2007) Economic Impact of Cattle Transfers during the CLP's Asset Transfer Programme, Dhaka: Chars Livelihood Programme

Mattinen, H. and Ogden, K. (2006) 'Cash-based Interventions: Lessons from Southern Somalia', Disasters 30.3: 297-315

McCord, A. (2005) 'Win-win or Lose-lose?: An Examination of the Use of Public Works as a Social Protection Instrument in Situations of Chronic Poverty', paper for presentation at the Conference on Social Protection for Chronic Poverty, Institute for Development Policy and Management, University of Manchester

Mechler, R.; Linnerooth-Bayer, J. and Peppiatt, D. (2006) Disaster Insurance for the Poor?: A Review of Microinsurance for Natural Disaster Risks in Developing Countries, Geneva and Laxenburg: ProVention and the International Institute for Applied Systems Analysis

Mitchell, T.; Tanner, T.M. and Wilkinson, E, (2006) Overcoming the Barriers: Mainstreaming Climate Change Adaptation in Developing Countries, Tearfund Climate Change Briefing Paper 1, Middlesex: Tearfund

Morduch, J. (2006) 'Micro-insurance: The Next Revolution?', in A. Banerjee, R. Benabou and D. Mookherjee (eds), Understanding Poverty, Oxford: Oxford University Press

O'Brien, K.; Eriksen, S.; Schjolden, A. and Nygaard, L. (2004) What's in a Word?: Conflicting Interpretations of Vulnerability in Climate Change Research, CICERO Working Paper 2004:04, Blindern, Norway: Center for International Climate and Environmental Research

Orindi, V.A. and Ochieng, A. (2005) 'Kenya Seed Fairs as a Drought Recovery Strategy in Kenya,' IDS Bulletin 36.4: 87-102

Paavola, J. and Adger, W.N. (2006) 'Fair Adaptation to Climate Change', Ecological Economics 56.4: 594-609

Pelham, L. and Assegid, R. (2006) Ethiopia's Productive Safety Net Programme: Assessment of Decision-making Processes and Preferences for Cash and/or Food Transfers, Washington: World Bank

PLOW (2007) Professional Development for Livelihoods: Agriculture and Pro Poor Growth theme page. Available at: www.passlivelihoods.org.uk/plow/ default.asp?id=198 (accessed on 13 July 2008)

Polack, E. (2008) 'A Right to Adaptation: Securing the Participation of Marginalised Groups', in T.M. Tanner and T. Mitchell (eds), 'Poverty in a Changing 
Climate', IDS Bulletin 39.4, September, Brighton: IDS

Richards, M. (2003) Poverty Reduction, Equity and Climate Change: Global Governance Synergies or Contradictions?, London: Overseas Development Institute (ODI)

Sabates-Wheeler, R.; Dorward, A.; MacAuslan, I. and Buckley, C.P. (2007a) Agriculture for Social Protection or Social Protection for Agriculture: Linking Policies for Pro-Poor Growth

Sabates-Wheeler, R.; Guenther, B. and MacAuslan, I. (2007b) Social Transfers and Policy Influence: DFID and the Politics of Influencing, DFID Social Transfers Evaluation, Brighton: IDS

Sen, A. (1981) Poverty and Famines, Oxford: Clarendon Press

Simms, A.; Magrath, J. and Reid, H. (eds) (2004) Up in Smoke: Threats from, and Responses to, the Impacts of Global Warming on Human Development, London: New Economics Foundation

Slater, R.; Ashley, S.; Tefera, M.; Buta, M. and Esubalew, D. (2006) Ethiopia Productive Safety Net Programme (PSNP): PSNP Policy, Programme and Institutional Linkages, London: Overseas Development Institute

Sperling, F. and Szekely, F. (2005) Disaster Risk Management in a Changing Climate, informal discussion paper prepared for the World Conference on Disaster Reduction on behalf of the Vulnerability and Adaptation Resource Group (VARG), Washington DC

Stern, N. (2006) The Economics of Climate Change: The Stern Review, Cambridge: Cambridge University Press

Tanner, T.M. and Mitchell, T. (eds) (2008a) 'Poverty in a Changing Climate', IDS Bulletin 39.4, September, Brighton: IDS

Tanner, T.M. and Mitchell, T. (2008b) Entrenchment or Enhancement: Could Climate Change Adaptation Help Reduce Chronic Poverty?, Chronic Poverty Research Centre Working Paper 106, Manchester: University of Manchester, Chronic Poverty Research Centre

Tanner, T.M.; Hassan, A.; Islam, K.M.N.; Conway, D.; Mechler, R.; Ahmed, R.U. and Alam, M. (2007) ORCHID: Piloting Climate Risk Screening in DFID Bangladesh - Research Report, Brighton: IDS

Thompson, J.; Millstone, E.; Scoones, I.; Ely, A.; Marshall, F.; Shah, E. and Stagl, S. (2007) Agri-food System Dynamics: Pathways to Sustainability in an Era of Uncertainty, STEPS Working Paper 4, Brighton: STEPS Centre

Tompkins, E.L. and Adger, W.N. (2004) 'Does Adaptive Management of Natural Resources Enhance Resilience to Climate Change?', Ecology and Society 9.2:10. Available online at: www.ecologyandsociety.org/vol9/iss2/art10/ (accessed 10 September 2008)

UNDP (2007) Human Development Report 2007/2008 Fighting Climate Change: Human Solidarity in a Divided World, New York: United Nations Development Programme 
(2004) Reducing Disaster Risk, A Challenge for Development, New York: UNDP Bureau for Crisis Prevention and Recovery

UNFCCC (2007) Local Coping Strategies Database. Available online at: http://maindb.unfccc.int/public/adaptation/ (accessed 10 September 2008)

Vaitla, B. (2006) Toward a Future Without Hunger?: The State of Food Security Policy and Programming in Ethiopia, Addis Ababa: Action Contre La Faim

Wisner, B.; Blaikie, P.; Cannon, T. and Davis, I. (2004) At Risk: Natural Hazards, People's Vulnerability and Disaster (2nd ed.), London and New York: Routledge 